\section{VERDADE E METALINGUAGEM EM LACAN}

Estilo e verdade na perspectiva da
crítica lacaniana à metalinguagem, de Gilson de Paulo Moreira Iannini, Belo Horizonte, Autêntica, 2012, 374 p.

\footnotetext{
Christian Ingo Lenz Dunker

Psicanalista, professor livre-docente do Instituto de Psicologia da USP, analista membro de Escola dos Fóruns do Campo Lacaniano, autor de Estrutura e constituição da clínica psicanalítica (AnnaBlume, 2011).
}

O trabalho de Gilson Iannini, originalmente sua tese de doutorado no Departamento de Filosofia da USP, sob a orientação de Vladimir Safatle, realiza três tarefas fundamentais para o que se pode chamar de reabilitação do tema da verdade em Lacan. Reabilitação, pois na maior parte dos comentadores e dos leitores de Lacan a conexão entre verdade e impossibilidade de metalinguagem aparece a serviço da estratégia de guarnição de três fronteiras.

A fronteira clínica na qual se discerne que a confiança na metalinguagem, carregada pela soberania do sentido e pelo poder discricionário da interpretação, atribuída ao analista, definiria o exercício de um poder cujo efeito seria a violência da interpretação. A crítica lacaniana da metalinguagem, neste caso, tem a função de guarnecer a interpretação liberadora de sentido, colhida do próprio texto e na preservação de sua ambiguidade, que se apresentaria em boa clínica lacaniana.
A fronteira epistemológica, na qual se compara a estratégia de fundamentação, derivada do positivismo-lógico (Carnap), do formalismo logicista (Frege) e do estruturalismo "kantiano” (Lévi-Strauss) com o uso lacaniano das matemáticas. Aqui a crítica da metalinguagem teria a função de preservar e de manter aberta a problemática da cientificidade da psicanálise, vetando a possibilidade de um discurso primeiro, de natureza metafísica, científica, lógica ou poética.

A fronteira ético-estética ou "linguageira”, na qual se estabelece uma atitude geral diante da linguagem, de seus limites e de sua assunção por aquele que fala. A fronteira aqui se opõe à normalização da linguagem exemplificada pelo programa de Ogden e Richards de estabelecer um inglês simplificado (Basic English), com base na aplicação de princípios de desambiguação como mediadores sanitários do laço social. Neste caso a crítica da metalinguagem serve para nos separar deste potencial terrorismo semântico, do qual recolhemos efeitos quer na tradição pragmática quer na tradição desconstrucionista e ainda no código de chavões retóricos que tão facilmente grassa em associações psicanalíticas.

Mas além de refazer a crítica da metalinguagem, apoiado no que de melhor a tradição da filosofia analítica nos trouxe como atitude advertida diante da linguagem, o texto reabilita o tema da verdade em Lacan para além da estratégia negativa de guarnição de fronteiras com base na separação entre clínica, epistemológica 
e estética. Ele refaz a crítica lacaniana da concepção positivista de ciência, do impulso à criação de linguagens artificiais e da perspectiva política calcada no humanitarismo sem hierarquizar a formalização e a linguagem natural.

Por meio de pequenos "experimentos”, reescreve-se a problemática lacaniana fora de seus próprios termos, mas sem trair seu plano de inteligibilidade. São pequenos "casos" linguísticos, discursivos e narrativos que fornecem o equivalente clínico e a leveza estilística que arejam o texto, substituindo a habitual prosa reverente pelo benéfico e raro estilo argumentativo.

O trabalho de Gilson Iannini torna-se assim uma contribuição essencial tanto para o estudo temático do conceito de verdade em Lacan quanto para o questionamento da função deste conceito para a clínica. O trabalho de reconstrução é sumamente justo. Propositivo sem ser demasiadamente apologético; rigoroso sem ser excessivamente técnico. Mas, poderíamos objetar: para que serve uma verdade menor, deflacionada, impotente, parcial? Não seria melhor chamar tal verdade de experiência, ela mesma. Ou ainda, um processo (Hegel), um percurso (Badiou), uma operação (Lacan), um caminho (Zizek)?

Uma verdade que ao final de seu processo, permanece apenas como um lugar não seria apenas uma forma tática de combater a mentira, o cinismo e a canalhice? Se pensamos que a metafísica é a tentativa de tapar o furo da política e se admitimos, com Lacan, que cada qual tem sua metafísica ou sua ontologia, chegamos à ideia de que a metalinguagem - seja ela tomada como conceitografia constituída ou como linguagem impregnada de formas de vida cotidianas — é a resposta característica da perversão ordinária, esta servidão voluntária da subjetividade em estado de condomínio. Recusa (Verleugnung) da verdade e normalização do Real.

A crença na metalinguagem é o cerne da atitude burocrática, do formalismo normativo, da vida "operacional metodológica” sugerida pelas disciplinas, da vida vivida por "alguém como você". Lembremos que a expressão canalhice designa um tipo de transferência, que Lacan hesita em considerar beneficamente tratável pela psicanálise, uma vez que deste canalha se produzirá um débil. Ou seja, um canalha é alguém apegado a um gozo débil defendido e encoberto pela convicção metalinguística.

O canalha é o intérprete parasita, o síndico da fala alheia, o gerente das enunciações, especialista na gestão da impostura e na arte de colocar sua própria enunciação como Outro do Outro. O que Wittgenstein se recusa a admitir em psicanálise é o mesmo que ele recusa à teoria dos conjuntos: sua ontologia. Não é possível dizer a verdade sobre o Real porque neste caso teríamos que estabelecer uma correspondência biunívoca entre a linguagem (dizer) e o mundo (real), bem como localizar um sujeito fora do mundo, lugar de onde ele poderia enunciar a verdade da relação entre o que se diz e o que é.

A antinomia maior da noção de verdade remonta o fato de que ela repele assintoticamente o Real, em sua não dialética com o gozo, assim como dele se aproxima em sua dialética com o saber. A grande cisão do pensamento lacaniano é entre Real e verdade, duas categorias tão inconciliáveis quanto inseparáveis. Neste sentido o "realismo da verdade" que Miller "diagnostica em Lacan, parece "tirado da cartola" e contraria quase todo o movimento da tese. Não há intersecção natural entre verdade e Real. Aqui está todo o antipositivismo de Lacan. A relação 
entre as categorias é de outro tipo, é uma relação de produção, não de verificação.

Desde a tese lacaniana de juventude da "psicanálise como método de verdade" até os últimos desdobramentos sobre a varidade (combinação de verdade e variedade) e desde o modelo elíptico das relações entre saber e verdade até a dialética fraturada da reabsorção da verdade ao saber até o sinthome como este laço entre heterogêneos (o traço sem fé da verdade) dizer que não há metalinguagem é dizer que não há linguagem objeto.

Em Lacan, não há confiança em categorias como tipos lógicos, classes de linguagens, universos de discurso, estratos de linguagem, língua denotativa, língua-objeto, linguagem semanticamente fechada (Tarski). Todas elas correspondem a decisões normativas infiltradas e revestidas de formalismo. Ou seja, a crítica da metalinguagem é um capítulo da valorização psicanalítica dos paradoxos de autorreferência não apenas uma estratégia de fundamentação. Aqui, o juízo de Iannini aponta novamente para a ontologia negativa: o que engendra paradoxos não é qualquer tipo de autorreferência, mas a tentativa de expressar conceitos formais através de funções proposicionais.

Esta é a tradução conceitual de máximas tais como: a verdade não-toda, o semi-dizer da verdade, a verdade em estrutura de ficção. Um princípio geral se depreende deste extenso e detalhado trabalho de pesquisa: o próprio discurso deve ser consistente, em sua maneira de dizer, com aquilo que diz. Há sim, uma ligação inextricável entre 0 que se diz, como se diz e sobre o que se diz. Esta solidariedade entre concepção de linguagem teorizada e praticada por Lacan não é nem a linguagem séria esperada do honnête-homme, nem uma ética discursiva ao modo de Habermas, nem mesmo uma moral terminológica como em Ogden e Richards, muito menos uma terapia linguística.

Contra a boa hipótese desenvolvida por Richard Simanke, de que em Lacan há uma concepção metafórica de teoria, Iannini problematiza e separa a metáfora surrealista da metáfora lacaniana. Separando a metáfora como processo que vai do simbólico ao Real da ficção como trajeto que vai do real ao simbólico, a ficção se alinha com o impossível enquanto a metáfora se alinha ao contingente.

Em suma, o leitor tem diante de si um ótimo exemplo do que a tradição brasileira de estudos lacanianos tem de melhor: cruzamento de perspectivas, combinação de fontes, mistura entre exegese e crítica, tensão entre clínica e política, presença e disseminação da possibilidade de pensar para além da reprodução metodológica de formas pré-constituídas.

Recebido em 20/8/2012.

Aprovado em 30/8/2012.

Christian Ingo Lenz Dunker

chrisdunker@usp.br

\section{A PSICANÁLISE É CONTRA-HEGEMÔNICA}

\section{Leituras da clínica, escritas da cultura, de Maria Cristina Poli, Campinas, Mercado de Letras, 2012, $192 \mathrm{p}$.}

\footnotetext{
Amadeu de Oliveira Weinmann

Professor do Departamento de Psicanálise e Psicopatologia do Instituto de Psicologia/ UFRGS.
}

Há vários motivos para saudar o lançamento de Leituras da clínica, escritas da cultura, de Maria Cristina Poli. A autora 